\title{
Inheritance of rice cold tolerance at the seedling stage
}

\author{
Renata Pereira da Cruz ${ }^{1 *}$; Ismael Tiago de Lima Duarte²; Caroline Cabreira ${ }^{3}$ \\ ${ }^{1} I R G A$ - Estação Experimental do Arroz, Seção de Melhoramento Genético, Av. Bonifácio Carvalho Bernardes, \\ 1494, C.P. 29 - 94930-030 - Cachoeirinha, RS - Brasil. \\ ${ }^{2}$ UFR GS - Programa de Pós-Graduação em Fitotecnia, Av. Bento Gonçalves, 7712 - 91540-000 - Porto Alegre, \\ RS - Brasil. \\ ${ }^{3}$ Unisinos - Graduação em Ciências Biológicas, Av. Unisinos, 950 - 93022-000 - São Leopoldo, RS - Brasil. \\ *Corresponding author <rpdacruz@hotmail.com>
}

\begin{abstract}
Rice (Oryza sativa L.) cold tolerance at the initial stages of development is a highly desirable trait to be incorporated into the state of Rio Grande do Sul, Brazil, cultivars, but selection for this trait must be performed under controlled temperature conditions, which limits the number of lines that can be evaluated. Knowledge of the inheritance of this trait is important to define breeding strategies. So the aim of this paper was to study the genetic basis of rice cold tolerance at the vegetative stage. Six genotypes with constrasting cold tolerance reactions were crossed in a diallel scheme without the reciprocals. The parents and the $\mathrm{F}_{1}$ and $\mathrm{F}_{2}$ generations were cultivated in a greenhouse until the $\mathrm{V}_{4}$ stage, when they were submitted to $10^{\circ} \mathrm{C}$ for ten days and evaluated for plant survival after seven days of recovery under normal temperature. The results obtained by the diallel analysis of the $\mathrm{F}_{1}$ generation indicated significance of both additive and non-additive effects, but the general combining ability was more important. The evaluation of the $\mathrm{F}_{2}$ generation revealed oligogenic inheritance with one or two dominant alleles responsible for cold tolerance in the cold tolerant parents and two complementary genes with recessive alleles segregating in the crosses involving sensitive and intermediate genotypes.

Key words: Oryza sativa L., genetics, low temperature, vegetative stage
\end{abstract}

\section{Herança da tolerância do arroz ao frio no estádio de plântula}

\begin{abstract}
RESUMO: A tolerância ao frio nos estádios iniciais de desenvolvimento do arroz (Oryza sativa L.) é uma característica altamente desejável para incorporar em cultivares do Rio Grande do Sul (RS), porém a seleção para esta característica deve ser feita sob condições de temperatura controlada, o que limita o número de linhas que pode ser avaliada. O conhecimento da herança desta característica é importante para definir estratégias de melhoramento genético, assim o objetivo do presente trabalho é estudar a base genética da tolerância ao frio no estádio vegetativo do arroz. Seis genótipos com reações contrastantes de tolerância ao frio foram cruzados num esquema dialélico sem os recíprocos. Os genitores e as gerações $\mathrm{F}_{1}$ e $\mathrm{F}_{2}$ foram cultivados em casa-de-vegetação até o estádio $\mathrm{V}_{4}$, quando foram submetidos a $10^{\circ} \mathrm{C}$ por dez dias e avaliados quanto à sobrevivência de plantas após sete dias de recuperação sob temperatura normal. Os resultados obtidos pela análise dialélica da geração $F_{1}$ indicaram significância tanto dos efeitos aditivos quanto não-aditivos, mas a capacidade geral de combinação foi mais importante. A avaliação da geração $F_{2}$ revelou uma herança oligogênica com um ou dois alelos dominantes responsáveis pela tolerância ao frio nos genitores tolerantes e dois genes complementares com alelos recessivos segregando nos cruzamentos envolvendo genótipos sensíveis e intermediários.
\end{abstract}

Palavras-chave: Oryza sativa L., genética, temperatura baixa, estádio vegetativo

\section{Introduction}

In the state of Rio Grande do Sul (RS), the Southern most state of Brazil, irrigated rice (Oryza sativa L.) crop is grown annually in an area of about one million ha. Due to the subtropical climate in this region, many areas are prone to cold weather damage in some stage of development. It is estimated that cold temperatures (below $20^{\circ} \mathrm{C}$ ) occur once every three years in RS, causing yield losses of around 20\% (Terres and Galli, 1985). The rice breeding program conducted by the Rio Grande do Sul Rice Institute (IRGA) is working towards developing rice cultivars with cold tolerance at the initial stages of development. Selection for cold tolerance is performed under controlled temperature conditions and a number of methodologies have already been developed and used for this purpose (Cruz and Milach, 2000). Determination of the most effective generation to select for cold tolerance is crucial for the efficiency of these indirect selection schemes. In this context, knowledge of the inheritance of cold tolerance at the vegetative stage is important to define when selection is likely to be more efficient, whether in early or advanced generations of the breeding program.

Conventional genetic studies of rice cold tolerance at the vegetative stage indicated a simple and oligogenic inheritance when evaluated by measuring chlorosis and yellowing of the leaves (Kwak et al., 1984; Nagamine and Nakagahra, 1991). Recently molecular studies have also found major quantitative trai loci (QTLs) associated

Sci. Agric. (Piracicaba, Braz.), v.67, n.6, p.669-674, November/December 2010 
with cold tolerance at seedling stage (Andaya and Mackill, 2003; Jiang et al., 2008; Lou et al., 2007; Zhang et al., 2005). However, continuous distribution of cold tolerance in the indica $\times$ japonica populations together with findings of minor QTLs explaining part of the variation points to a more complex inheritance for cold tolerance at seedling stage (Han et al., 2005; Lou et al., 2007; Qian et al., 2000; Zhang et al., 2005).

Such studies have not been performed with Brazilian genotypes yet, and as the number of genes and gene action depend on the genetic material studied, it is of fundamental importance to know the genetic basis of cold tolerance of breeding lines and cultivars currently used in our breeding programs in order to establish a more efficient breeding strategy under controlled temperature conditions.

\section{Material and Methods}

The experiments were conducted under greenhouse and controlled temperature room in Cachoeirinha, RS,

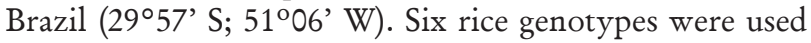
as parents in a complete diallel crossing scheme, without the reciprocals, amounting 15 combinations. Three of them belong to the japonica subspecies and are cold tolerant (Rizabela, Alan and L2825CA) and the other three belong to the indica subspecies and have intermediate or sensitive reaction to cold temperature at seedling stage (INIA Olimar, IRGA 2852-20-4-3-3V and IRGA 424). For ease of use, from now on the line IRGA 285220-4-3-3V will be referred to as only IRGA 2852 . The crosses were performed in the 2007/08 growing season and on the following winter season some of the $F_{1}$ seeds were cultivated in $5 \mathrm{~L}$ plastic pots filled with field soil and kept in a greenhouse $\left(28^{\circ} \mathrm{C}\right)$ in order to obtain the $\mathrm{F}_{2}$ seeds.

Experiment I was conducted from June to July 2008. Seeds of the six parents and of the $15 \mathrm{~F}_{1}$ hybrids obtained in the partial diallel were sowed in Petri dishes with two pieces of moist germination paper and set to germinate at $28^{\circ} \mathrm{C}$ in a BOD chamber. After five to seven days they were transplanted to trays filled with organic soil and kept in a greenhouse with controlled temperature $\left(28^{\circ} \mathrm{C}\right.$ $\pm 2^{\circ} \mathrm{C}$ ). The experimental design was completely randomized blocks with four replications and ten plants of each parent and $F_{1}$ hybrid per replication. Plants were kept at the greenhouse until $\mathrm{V}_{3}-\mathrm{V}_{4}$ stage (Counce et al., 2000) when they were taken to a controlled temperature and artificially lighted room at $10^{\circ} \mathrm{C}$ for ten days. After this period the plants were taken back to the greenhouse and evaluated for percentage of plant survival after seven days of recovery under normal temperature $\left(28^{\circ} \mathrm{C}\right)$.

Data for the parents and $F_{1}$ 's were submitted to analysis of variance and comparison of means using SNK test $(\alpha=0.05)$, all performed in the SAS program (SAS Institute, 2000). Diallel analysis was performed using the GENES software (Cruz, 2006) according to the model proposed by Griffing (1956), method 2, considering a fixed model without the reciprocals.
Quadratic components for the fixed model were estimated according to Cruz and Regazzi (1994):

$\phi_{\mathrm{g}}=\mathrm{GMS}-\mathrm{EMS} / \mathrm{p}+2$

$\phi_{\mathrm{s}}=\mathrm{SMS}-\mathrm{EMS}$

where $\phi_{\mathrm{g}}=$ quadratic component associated to the general combining ability (GCA); $\phi_{s}=$ quadratic component associated to the specific combining ability (SCA); GMS $=$ GCA Mean Square; EMS = Error Mean Square; SMS $=$ SCA Mean Square, and $\mathrm{p}=$ number of parents in the diallel.

Experiment II was performed from January to July 2009. Pre-germinated seeds of the parents and of $10 \mathrm{~F}_{2}$ populations were transplanted to trays filled with organic soil and kept in a greenhouse with controlled temperature $\left(28^{\circ} \mathrm{C} \pm 2^{\circ} \mathrm{C}\right)$. A variable number of $\mathrm{F}_{2}$ plants was evaluated per population, depending on the availability of seed. In general, for each $\mathrm{F}_{2}$ population three trays of 150 cells were used, with $130 \mathrm{~F}_{2}$ plants and 10 plants for each parental genotype per tray. Only ten $\mathrm{F}_{2}$ populations were evaluated in this experiment due to lack of enough $F_{2}$ seeds for the remaining five populations of the diallel. The conduction of the experiment and cold tolerance evaluation were performed as described for experiment I.

The parents were evaluated by an analysis of variance of the percentage of plant survival in a completely randomized design with a variable number of replications, depending on the number of crosses they were included. Comparison of means was made by the least square test. All these analysis were performed in the SAS program (SAS Institute, 2000). The $\mathrm{F}_{2}$ populations were evaluated by counting the number of surviving and non-surviving plants in each and the data was submitted to the Chi-Square test to verify adjustment to the theoretical proportions expected for one and two independent genes and two complementary genes segregating. Chi-Square values were obtained through the following formula: $\chi^{2}=\Sigma\left(\mathrm{F}_{\mathrm{o}}-\mathrm{F}_{\mathrm{e}}\right)^{2} / \mathrm{F}_{\mathrm{e}}$, where $\mathrm{F}_{\mathrm{o}}=$ observed frequency for each class; and $\mathrm{F}_{\mathrm{e}}=$ expected frequency for each class, based on the Mendelian proportion.

\section{Results}

Analysis of variance showed a highly significant variation among replications, genotypes, General Combining Ability (GCA) and Specific Combining Ability (SCA) for percentage of plant survival (Table 1). The significance of GCA and SCA indicates that the parents differed in relation to the general combining ability (GCA) and the hybrids presented distinct specific combining abilities (SCA) (Table 1). It also indicates that both additive and non-additive genetic effects are involved in the inheritance of the trait. However, the higher magnitude of the GCA component means that additive gene action is predominant over non-additivity (Table 1). On the other hand, quadratic component associated to SCA presented higher magnitude than the 
one associated to GCA (Table 1). In the fixed model, the quadratic components express the genetic variability of the genotypes studied (Cruz and Regazzi, 1994). The superiority of the quadratic component associated to SCA is observed in previous selected genetic material, in which the differential for additive effects may be reduced. This is the case here, where parental genotypes are very contrasting and belong to two subspecies that have developed adaptation to specific environments, like cold temperature tolerance in the case of japonica. So, these ones have, in fact, been previously selected for cold tolerance as they originated from colder regions.

There was a large variation among parental genotypes (Table 2), with the three japonica genotypes pre-

Table 1 - Analysis of variance for percentage of plant survival from cold treatment evaluated in a diallel involving six parents and $15 \mathrm{~F}_{1}$ hybrids without the reciprocals.

\begin{tabular}{lcc}
\hline Source of variation & Degrees of freedom & Mean Square \\
\hline Replications & 3 & $968.17 * \%$ \\
Treatments & 20 & $2191.48 * \%$ \\
GCA & 5 & $5152.82 * \%$ \\
SCA & 15 & $1204.36 *$ \\
Error & 58 & 242.98 \\
\hline $\mathrm{R}^{2}=0.76$ & $\phi^{1}=613.73$ & \\
CV $(\%)=19.1$ & $\phi s^{2}=961.38$ & \\
\hline
\end{tabular}

Key: GCA = general combining ability; SCA = specific combining ability. $* *$ Significant $(\alpha=0.01)$. ${ }^{1}$ Quadratic component associated with the GCA. ${ }^{2}$ Quadratic component associated with the SCA. senting the higher percentage of survival, all classified as tolerant to cold at seedling stage. Among indica genotypes, INIA Olimar presented an intermediate behaviour and IRGA 2852 and IRGA 424 a sensitive reaction (Table 2).

Regarding the $\mathrm{F}_{1}$ hybrids, the majority presented a tolerant reaction, with more than $80 \%$ of plant survival. This clearly demonstrates a dominant gene action for cold tolerance as evaluated by the percentage of plant survival in these genotypes. The only exception were the two crosses between sensitive parents, in which IRGA 424 was one of them, that presented intermediate reaction (between 30 and $70 \%$ of plant survival) (Table 2).

In absolute terms, almost all F1's presented higher plant survival than both of the parents, indicating overdominance for cold tolerance. The exceptions were the crosses Rizabela $\times$ IRGA 2852 and Rizabela $\times$ IRGA 424 . However, statistically all the $\mathrm{F}_{1}$ 's did not differ from one of the parents, indicating dominance for cold tolerance (Table 2). By these results it is evident the importance of non-additivity for cold tolerance at the vegetative stage.

The parental performance per se seemed to be a good index of their GCA effects for cold tolerance, as the japonica parents showed positive values for GCA effects and the indica genotypes negative values (Table 3 ). The three tolerant genotypes had significant and positive GCA estimates, indicating that all of them present good combing ability to be used as donors to transfer cold tolerance to sensitive genotypes (Table 3). Among the cold sensitive parents, IRGA 424 was the worst genotype as a donor for this trait (Table 3), as it can be seen by its low plant survival rate (Table 2).

Table 2 - Percentage of plant survival from cold treatment for the six parents and $15 \mathrm{~F}_{1}$ hybrids.

\begin{tabular}{lcccccc}
\hline & Rizabela & Alan & L2825CA & INIA Olimar & IRGA 2852 & IRGA 424 \\
\hline Rizabela & $92.6 \mathrm{a}^{1}$ & $97.5 \mathrm{a}$ & $100.0 \mathrm{a}$ & $100.0 \mathrm{a}$ & $92.2 \mathrm{a}$ & $92.2 \mathrm{a}$ \\
Alan & & $80.7 \mathrm{ab}$ & $97.5 \mathrm{a}$ & $97.5 \mathrm{a}$ & $97.5 \mathrm{a}$ & $97.5 \mathrm{a}$ \\
L2825CA & & $83.0 \mathrm{ab}$ & $91.4 \mathrm{a}$ & $92.5 \mathrm{a}$ & $97.5 \mathrm{a}$ \\
INIA Olimar & & & & $52.9 \mathrm{bc}$ & $80.1 \mathrm{ab}$ & $55.3 \mathrm{bc}$ \\
IRGA 2852 & & & & & $30.6 \mathrm{c}$ & $43.1 \mathrm{c}$ \\
IRGA 424 & & & & & $10.3 \mathrm{~d}$ \\
\hline
\end{tabular}

${ }^{1}$ Means followed by the same letter do not differ (SNK test, $\alpha=0.05$ ).

Table 3 - General combining ability (GCA) and specific combining ability (SCA) effects of six rice genotypes and their hybrids for percentage of plant survival after cold treatment.

\begin{tabular}{|c|c|c|c|c|c|c|c|}
\hline & Rizabela & Alan & L2825CA & INIA Olimar & IRGA 2852 & IRGA 424 & GCA \\
\hline Rizabela & $-14.59 \%$ & $-6.40 *$ & -3.51 & $6.20 *$ & $6.09 *$ & $18.64 \%$ & $12.79 * \%$ \\
\hline Alan & & $-19.90 \%$ & -2.71 & $6.99 *$ & $14.68 \% *$ & $27.23 * *$ & $9.50 *$ \\
\hline L2825CA & & & $-16.82 \%$ & 1.29 & $10.08 *$ & $27.63 *$ & $9.11 *$ \\
\hline INIA Olimar & & & & $-8.50 \%$ & $7.38 \%$ & -4.87 & -0.59 \\
\hline IRGA 2852 & & & & & $-14.43 *$ & $-9.38 *$ & $-8.28 *$ \\
\hline IRGA 424 & & & & & & $-29.63 * *$ & $-20.83^{* *}$ \\
\hline
\end{tabular}

* Significant $(\alpha=0.05)$. * Significant $(\alpha=0.01)$. 
The hybrids between japonica cold tolerant genotypes presented negative values for SCA, indicating that no increment in cold tolerance might be gained by crossing these genotypes. On the other hand, the crosses involving a japonica parent and an indica one showed only positive effects for SCA, revealing existence of heterosis for plant survival (Table 3). Most of them were significant, with the exception of the cross L2825CA $\times$ INIA Olimar, indicating almost no heterosis in this combination. Among the japonica $x$ indica crosses the highest heterosis was found in the combinations involving IRGA 424 as the sensitive parent. Among the indica genotypes, the only combination that produced positive and significant SCA effects was INIA Olimar $\times$ IRGA 2852, indicating that this cross exhibits heterosis for cold tolerance.

The SCA values for the parents have a genetic meaning both in their signal as well as their magnitude. The negative value means existence of unidirectional dominance deviations, so positive heterosis in hybrids between divergent parents. The high magnitude means high genetic divergence of a genotype in relation to the mean of the others and so, high heterosis in the hybrids. In the present case all parents presented negative and significant SCA effects, with the highest magnitude found in Alan and IRGA 424. In fact these were the parents that provided the highest positive heterosis considering all hybrid combinations (Table 3 ).

Parental means in experiment II had a wide variation from $2.5 \%$ of plant survival in IRGA 424 to $97.7 \%$ in Rizabela (Table 4). This cold reaction is quite similar to the results obtained in experiment I (Table 2), classifying Rizabela, Alan and L2825CA as cold tolerant (more than $70 \%$ of plant survival), INIA Olimar as intermediate (between 40 and $70 \%$ of plant survival) and IRGA 2852 and IRGA 424 as sensitive (below 40\% of plant survival). Results relative to the $\mathrm{F}_{2}$ generation revealed that in populations in which there was at least one cold tolerant parent (japonica $\times$ japonica and japonica $\times$ indica), there was a predominance of surviving plants, indicating dominance gene action for tolerance is these crosses (Table 5, Figures 1 and 2). On the other hand, in the sensitive $\times$ intermediate crosses (indica $\times$ indica) there were more non-surviving plants than surviving, and in the sensitive $\times$ sensitive cross (indica $\times$ indica) there were no surviving plants at all (Table 5 and Figure 1).

Among the cold tolerant parents, the population Alan $\times$ Rizabela presented one dominant allele segregating for cold tolerance and Rizabela $\times$ L2825CA presented two independent genes with dominant alleles segregating for this trait. The population Alan $\times$ L2825CA did not fit into any of the genetic hypothesis tested (Table 5). The crosses involving tolerant $\times$ sensitive genotypes showed two independent genes with dominant alleles segregating for cold tolerance (Table 5).

The cultivar INIA Olimar presents a two gene difference from the sensitive genotypes. In the population IRGA $424 \times$ INIA Olimar there are two independent genes with recessive alleles segregating for cold tolerance and in IRGA $2852 \times$ INIA Olimar there are two complementary genes with recessive alleles segregating for cold tolerance (Table 5). The genetic analysis evi-

Table 4 - Percentage of plant survival of the parents used in the study of the inheritance of cold tolerance at the seedling stage of rice.

\begin{tabular}{lc}
\hline Genotype & Mean of plant survival (\%) \\
\hline Rizabela & $97.7 \mathrm{a}$ \\
\hline L2825CA & $83.3 \mathrm{~b}$ \\
Alan & $81.8 \mathrm{~b}$ \\
INIA Olimar & $56.6 \mathrm{c}$ \\
IRGA 2852 & $22.2 \mathrm{~d}$ \\
IRGA 424 & $2.5 \mathrm{e}$ \\
\hline
\end{tabular}

Means followed by the same letter do not differ (least square test, $\alpha=0.05$ )

Table 5 - Number of surviving and non-surviving plants, total number of plants and adjustment of the Chi-Square test for $10 \mathrm{~F}_{2}$ populations of rice evaluated for cold tolerance at seedling stage.

\begin{tabular}{|c|c|c|c|c|c|c|}
\hline \multirow{2}{*}{ Population } & \multicolumn{3}{|c|}{ Number of plants } & \multicolumn{3}{|c|}{ Chi-Square } \\
\hline & Surviving & Non- Surviving & Total & $3: 1$ & $15: 1$ & $9: 7$ \\
\hline Alan $(\mathrm{T}) \times$ Rizabela $(\mathrm{T})$ & 277 & 107 & 384 & 1.7 & $306.1 * *$ & $39.4 * *$ \\
\hline Alan $(\mathrm{T}) \times$ L2825CA $(\mathrm{T})$ & 334 & 39 & 373 & $42.1 \% *$ & $11.3^{* * *}$ & $168.0 \% *$ \\
\hline Rizabela $(\mathrm{T}) \times$ L2825CA $(\mathrm{T})$ & 365 & 13 & 378 & $93.7 * \%$ & 5.1 & $249.6^{* * *}$ \\
\hline Alan $(\mathrm{T}) \times \operatorname{IRGA} 424(\mathrm{~S})$ & 363 & 17 & 380 & $85.4^{* *}$ & 2.0 & $238.2^{2 * *}$ \\
\hline Alan $(\mathrm{T}) \times$ IRGA $2852(\mathrm{~S})$ & 367 & 17 & 384 & $86.7 * *$ & 2.2 & $241.3^{* * *}$ \\
\hline Rizabela (T) × IRGA $2852(\mathrm{~S})$ & 231 & 6 & 237 & $63.8^{* *}$ & 5.6 & $163.6 \% *$ \\
\hline L2825CA (T) × IRGA $2852(\mathrm{~S})$ & 368 & 17 & 385 & $87.0 \% *$ & 2.2 & $242.1 * *$ \\
\hline IRGA $424($ S) $\times$ INIA Olimar (I) & 12 & 321 & 333 & $905.3^{* *}$ & 4.1 & $219.0 \% *$ \\
\hline IRGA $2852(\mathrm{~S}) \times$ IRGA $424(\mathrm{~S})$ & 0 & 358 & 358 & $1074.0 \% *$ & $23.4^{* * *}$ & $279.6 \% *$ \\
\hline IRGA $2852(\mathrm{~S}) \times$ INIA Olimar (I) & 114 & 127 & 241 & $98.6 *$ & $696.8^{* *}$ & 1.4 \\
\hline
\end{tabular}

$\chi_{.01(1)}^{2}=6.64 . *$ Significant $(\alpha=0.01)$.

Sci. Agric. (Piracicaba, Braz.), v.67, n.6, p.669-674, November/December 2010 


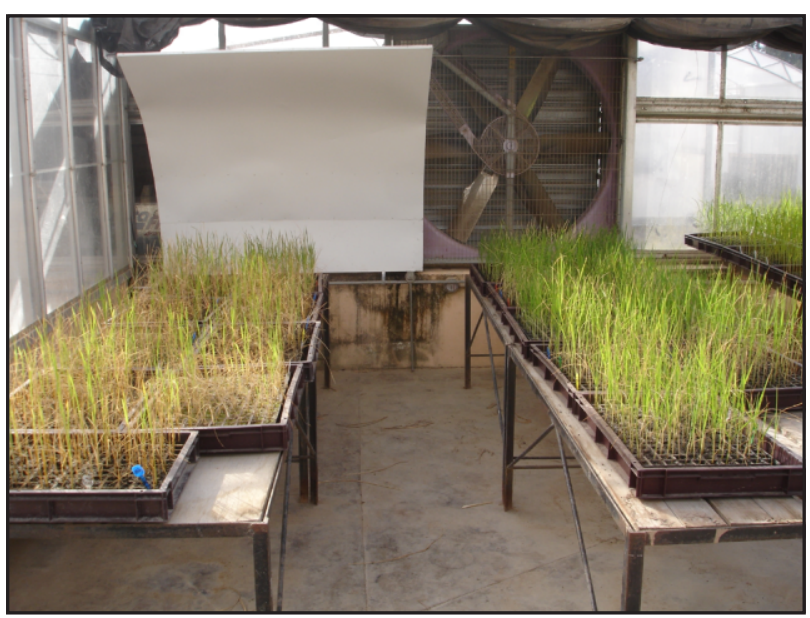

Figure 1 - Status of the $\mathrm{F}_{2}$ generation of the indica $\times$ indica crosses (left) and of the japonica $\times$ japonica crosses (right) seven days after recovery in greenhouse $\left(28^{\circ} \mathrm{C}\right)$ from the cold treatment of $10^{\circ} \mathrm{C}$ for ten days at the $\mathrm{V}_{3}$ stage.

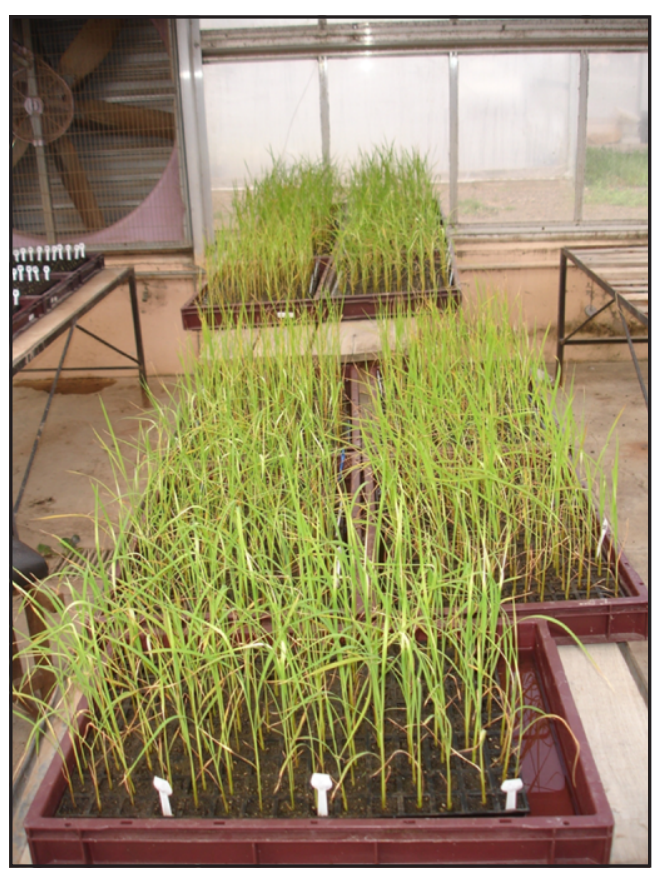

Figure 2 - Status of the $\mathrm{F}_{2}$ generation of the indica $\times$ japonica crosses seven days after recovery in greenhouse $\left(28^{\circ} \mathrm{C}\right)$ from the cold treatment of $10^{\circ} \mathrm{C}$ for ten days at the $\mathrm{V}_{3}$ stage.

denced a monogenic and oligogenic inheritance for cold tolerance at seedling stage in rice, with one or two genes segregating in the populations studied (Table 5). Cold tolerance at the seedling stage has a simple genetic basis in the populations studied, with dominant alleles in the cold tolerant parents and recessive alleles in the intermediate genotype INIA Olimar. The complementary genes segregating in the cross IRGA $2852 \times$ INIA Olimar indicates that IRGA 2852 might possess a recessive allele for cold tolerance as well.

\section{Discussion}

In this study rice cold tolerance at seedling stage was evaluated by the percentage of survival after exposing plants at the $\mathrm{V}_{3}$ stage to cold temperature $\left(10^{\circ} \mathrm{C}\right)$ for ten days. In genetical studies the mode of inheritance determined is valid only for the evaluated trait, the genetical material studied and, in this case, the intensity and duration of stress imposed (Cruz and Milach, 2000). In the present case, cold tolerance has a simple genetic basis with both additive and dominance gene action involved (Tables 1 and 5). Similar results were also obtained in genetic studies performed under controlled temperature conditions (Kwak et al., 1984; Kaw and Khush, 1986; Nagamine and Nakagahra, 1991; Shahi and Khush, 1986), like we have done here, indicating feasibility of selection for cold tolerance under these conditions.

Molecular approaches such as QTL mapping have been employed to study the genetic architecture of important agronomic traits. In the case of rice cold tolerance at the seedling stage a range of stress conditions has been applied, with some of them relating major QTLs involved in cold tolerance (Andaya and Mackill, 2003; Lou et al., 2007) while others have found both major and minor QTLs controlling this trait (Jiang et al., 2008; Zhang et al., 2005).

All these results were obtained in recombinant inbred lines (RILs) or double haploid (DH) populations between indica $\times$ japonica parents, such as in our study. The japonica parents contributed with major dominant alleles for cold tolerance and in the indica crosses recessive alleles and epistatic interaction were detected (Table 5). By evaluation of seedling mortality of 71 RILs, Jiang et al. (2008) found three QTLs related to cold tolerance, one major QTL contributed by the japonica parent and two minor QTLs from the indica one. Epistatic interactions have also been related in the control of seedling cold tolerance in rice (Lou et al., 2007; Zhang et al., 2005) and in low temperature germination ability (Chen et al., 2006).

The existence of segregation in the crosses $\mathrm{T} \times \mathrm{T}$ (Table 5) indicates that the cold tolerant genotypes studied carry different genes for cold tolerance. This means that these genes may probably be grouped into a single genotype, but for this molecular markers are necessary in order to differentiate the genes and allow for selection. Approaches like genetic transformation and gene expression have shown that many different pathways may be involved in rice cold tolerance at seedling stage, with genes for ascobarte peroxidase (Sato et al., 2001), fructan synthesis (Kawakami et al., 2008) and a transcription factor (Wang et al., 2003) associated with increased levels of tolerance. Differences in the activity and accumulation of oxidative enzymes and sugars were found between a cold sensitive genotype and a cold tolerant one (Morsy et al., 2007), corroborating the related above. These results suggest that many different genes may be involved with rice seedling cold tolerance, as has been 
found in some QTL studies (Han et al., 2005; Qian et al., 2000). But they do not exclude the possibility of one or more major genes being involved, as may be the case with transcription factors.

Diallel analysis showed the importance of both additive and non additive gene action in rice seedling cold tolerance. This has also been found in low temperature germination studies (Cruz et al., 2006; Sharifi, 2008) where both GCA and SCA were significant. Similarly to the results reported here, those studies found that GCA was of higher magnitude, suggesting the greater importance of additive effects. All this indicates that selection for cold tolerance may be effective in crosses between contrasting genotypes like the indica $\times$ japonica. The aim of studying the genetic basis of cold tolerance at seedling stage was to establish when to apply selection pressure, if in early generations of the breeding program or in advanced ones. Selection pressure under controlled temperature conditions may be useful in early generations, as only two genes with dominant alleles were found segregating in $\mathrm{T} \times \mathrm{S}$ crosses. However, as the dominant alleles were responsible for tolerance, progeny tests are necessary.

The three japonica parents evaluated are good donors for cold tolerance genes, as showed by their high GCA effects (Table 3) and as related by Kaw and Khush (1986) parental performance per se was a good index of the GCA effects for cold tolerance. According to the SCA effects, the crosses involving any of the japonica parents versus IRGA 424 are the most favourable ones to select superior genotypes.

\section{Acknowledgements}

To the Brazilian PIBIC/CNPq for the scholarships provided on this project.

\section{References}

Andaya, V.C.; Mackill, D.J. 2003. Mapping of QTLs associated with cold tolerance during the vegetative stage in rice. Journal of Experimental Botany 54: 2579-2585.

Chen, L.; Lou, Q.; Sun, Z.; Xing, Y.; Yu, X.; Luo, L. 2006. QTL mapping of low temperature on germination rate of rice. Rice Science 13: 93-98.

Counce, P.A.; Keisling, T.C.; Mitchell, A.J. 2000. A uniform, objective, and adaptive system for expressing rice development. Crop Science 40: 436443.

Cruz, C.D. 2006. Genes Program-Biometry. UFV, Viçosa, MG, Brazil. (in Portuguese).

Cruz, C.D.; Regazzi, A.J. 1994. Applied Biometrical Models in Genetic Breeding. UFV, Viçosa, MG, Brazil. (in Portuguese).

Cruz, R.P.; Milach, S.C.K. 2000. Genetic breeding for cold tolerance in irrigated rice. Ciência Rural 30: 909-917. (in Portuguese, with abstract in English).

Cruz, R.P.; Milach, S.C.K.; Federizzi, L.C. 2006. Inheritance of rice cold tolerance at the germination stage. Genetics and Molecular Biology 29: 314-320.
Griffing, B. 1956. Concept of general and specific combining ability in relation to diallel crossing systems. Australian Journal of Biological Sciences 9: 463-493.

Han, L.; Qiao, Y.; Cao, G.; Zhang, Y.; An, Y.; Ye, J.; Koh, H. 2005. QTL analysis on cold tolerance during early growth period in rice. Chinese Journal of Rice Science 19: 122-126.

Jiang, L.; Xun, M.; Wang, J.; Wan, J. 2008. QTL analysis of cold tolerance at seedling stage in rice (Oryza sativa L.) using recombination inbred lines. Journal of Cereal Science 48: 173179.

Kaw, R.N.; Khush, G.S. 1986. Combining ability for low-temperature tolerance in rice. p. 593-612. In: International Rice Research Institute [IRRI]. Proceedings of the International Rice Genetics Symposium. IRRI, Los Baños, Philippines.

Kawakami, A.; Sato, Y.; Yoshida, M. 2008. Genetic engineering of rice capable of synthesizing fructans and enhancing chilling tolerance. Journal of Experimental Botany 59: 793-802.

Kwak, T.S.; Vergara, B.S.; Nanda, J.S.; Coffman, W.R. 1984. Inheritance of seedling cold tolerance in rice. Sabrao Journal 16: 83-86.

Lou, Q.; Chen, L.; Sun, Z.; Xing, Y.; Li, J.; Xu, X.; Mei, H.; Luo, L. 2007. A major QTL associated with cold tolerance at seedling stage in rice (Oryza sativa L.). Euphytica 158: 87-94.

Morsy, M.R.; Jouve, L.; Hausman, J.F.; Hoffmann, L.; Stewart, J.M. 2007. Alteration of oxidative and carbohydrate metabolism under abiotic stress in two rice (Oryza sativa L.) genotypes contrasting in chilling tolerance. Journal of Plant Physiology 164: 157-167.

Nagamine, T.; Nakagahra, M. 1991. Genetic control of chilling injury in rice seedlings detected by low-temperature treatment. p. 737-739. In: International Rice Research Institute [IRRI]. Proceedings of the International Rice Genetics Symposium. IRRI, Los Baños, Philippines.

Qian, Q.; Zeng, D.; He, P.; Zheng, X.; Chen, Y.; Zhu, L. 2000. QTL analysis of the rice seedling cold tolerance in a doubled haploid population derived from anther culture of a hybrid between indica and japonica rice. Chinese Science Bulletin 45: 448-453.

SAS Institute. 2000. System for information: version 8.0. SAS Institute, Cary, NC, USA.

Sato, Y.; Murakami, T.; Funatsuki, H.; Matsuba, S.; Saruyama, H.; Tanida, M. 2001. Heat shock-mediated APX gene expression and protection against chilling injury in rice seedlings. Journal of Experimental Botany 52: 145-151.

Shahi, B.B.; Khush, G.S. 1986. Genetic analysis of cold tolerance in rice. p. 429-435. In: International Rice Research Institute [IRRI]. Proceedings of the International Rice Genetics Symposium. IRRI, Los Baños, Philippines.

Sharifi, P. 2008. Inheritance of cold tolerance in rice at the germination stage. Asian Journal of Plant Science 7: 485-489.

Terres, A.L.; Galli, J. 1985. Cold effects on irrigated rice cultivars in Rio Grande do Sul - 1984. p. 83-94. In: Embrapa. Fundamentals for irrigated rice crop. Cargill Foundation, Campinas, SP, Brazil. (in Portuguese).

Wang, Y.J.; Zhang, Z.G.; He, X.J.; Zhou, H.L.; Wen, Y.X.; Dai, J.X.; Zhang, J.S.; Chen, S.Y. 2003. A rice transcription factor OsbHLH1 is involved in cold stress response. Theoretical and Applied Genetics 107: 1402-1409.

Zhang, Z.H.; Su, L.; Li, W.; Chen, W.; Zhu, Y.G. 2005. A major QTL conferring cold tolerance at the early seedling stage using recombinant inbred lines of rice (Oryza sativa L.). Plant Science 168: $527-534$

Received January 14, 2010

Accepted May 14, 2010 